\title{
Development and Utilization of Human Resource in the Municipalities of Greece: The Case of Trikala Municipality
}

\author{
N. Blanas \\ Associate Professor, Department of Business Administration, T.E.I. of Thessaly \\ Email : nikoblan@teilar.gr \\ I. Grigoriou \\ BSc Aristotle University of Thessaloniki, MBA University of Staffordshire, \\ Email : ioangri@yahoo.gr

\section{Kyriakou} \\ Economist, BSc, MBA University of Liverpool, MSc Tourism Management University of Surrey, \\ Email : dimk21@gmail.com

\section{Belias} \\ PhD Cand, Department of Physical Education \& Sport Science, University of Thessaly \\ Email : dbelias@pe.uth.gr
}

\section{Doi:10.5901/mjss.2014.v5n27p145}

\section{Abstract}

\begin{abstract}
Chronic pathology suffering from the Greek government, especially local government and the reform imposed by the local municipalities program of Kallikratis combined with the economic crisis and the troika are the main reasons occupying this research and how through internal forces can municipalities find their way to a viable future. This work focuses on two levels. Firstly it records the current status of human resource in the Municipality of Trikala as well as it proposes a reorganization and restructuring of the foundations and management of human resources in this municipality aiming to a full utilization of capacities and skills. For this reason, the theory of human resources management with special thematic section on the development of human resources were examined in combination with the institution of local government in Greece. Particular attention was given to the introduction of the Kallikratis program and its impact within institutional, organizational, administrative, economic, and social level. Finally, this work tried to study the current status of human resource, especially in municipalities merged into a new municipality of Kallikratis program and how the new assessment system has helped to develop their abilities and skills. Moreover, what would be an ideal model for training and development of employees and what criteria exist for the relocation of employees in the proper position without conflicts. Ending and adding to this latter, what kind of conflicts were grown and how to handle them as well as to study motion reorganization of human resource for better utilization of capacities and skills.
\end{abstract}

Keywords: HRM, HR Development, Public Administration, Management, Employee Relations

\section{Introduction}

The L. 3852/2010 "The new architecture of the government and the devolved administration - Program Kallikratis", known as "Kallikratis", from the name of famous ancient Architect Kallikratis, enforces mergers and enlargement of administrative limits, as well as the implementation of new measures on behalf of Greek state, European Community and IMF.

The new architecture of regional and local self-government and devolved administration (L. 3852/2010), proceeded to change the administrative division of Greece and reordered the local government units, the way chosen by the institutions and their powers. The general secretaries of which took over the responsibilities of the old regions and 74 regional units (Ragousis, 2010).

Assumptions to be considered as facts are that according to the Kallikratis program the new municipalities would achieve better organization within their optimal organization to better serve the citizens of even the most remote 
communities while the program could achieve a better utilization of human resources with the logic of internal movements within the new municipality deploying extra employees in the proper and suitable position.

The first objective is to define the way they perceive the management changes and prospects of their employees in municipalities. The second regards to the objectives developed within the organization and finally to study how to implement best management practices in the new municipalities.

\section{Human Resource Management}

According to Anderson (1993:3), human resource management is based on the planning, control, evaluation and development. Strategic human resource management can fulfill many conditions of any organization such as "the support from the top of management, a strong culture which reinforces human resource management, a conscious strategy to achieve business success, and an ability to get Human Resources Management policies into place".

The objectives of human resource management should increase the competitiveness, productivity improvement, compliance with social obligations and employee satisfaction (Vaxevanidou et al, 2008). Human resource management plays a crucial and catalytic role in the proper functioning of a business (Noe et al, 2009, Dessler, 2012). The process of management can take different forms. Many companies give an important role to management in determining the efficiency and competitiveness. Competitiveness is maintaining firm's ability in the market and has a valuable stake in this. Directly related to the efficiency and means how can the particular companies meet its members (shareholders or customers). This strategy forms the basis of the management of human resources.

The practices and policies concerning personnel matters are managing human resources. These practices include defining policies of each worker, the attraction to different jobs, determining needs for proper function, selection, training and development of employees, management salaries, incentives and end the communication (Dessler, 2012).

The steps to be followed by the scheduling system of manpower are initial research, forecasting, planning, implementation and evaluation of the end system. The research should study strategies and human resource processes, identify problems and analyze labor market. The prediction should analyze variables from wherever they come from, to determine the demand and supply of manpower. Planning should build strategic planning, putting specific goals, identify resources and establish criteria. The application should manage the available resources and the monitoring and evaluation should follow procedures to evaluate and finally inform the management for results (Vaxevanidou et al, 2008; Latham, 2004; Cho et al, 2005).

The role of the department of human resource is essentially the connection between function of human resource management and business strategy. Traditional and then for many years the personnel department dealing only hiring and dismissal of persons and the assessment of which was only one (Mishra, 2010). Personnel departments are used to design the company policy while evaluating how the hiring or layoff will affect their business objectives by proposing solutions in nowadays (Mouza et al, 2006). Specifically personnel departments most in the short term assess staff solves any problems created, conducts training programs and employee training, developing programs better evaluation of personnel, creates "assessment centers" and develop plans for the professional development of its employees. In the long run it helps the business to progress in the future, the business strategy is influenced by internal factors such as the size of the business unit, the technology used, the lifecycle of the business, but also by external factors such as the strategy to be followed by the company in order to be competitive, cultural factors and the labor market (Werther et al, 1985).

The functions of human resources are initially staffing including job analysis, attracting staff and selecting the most suitable candidate for the job offered. Below is the evaluation function that includes the prerequisites for effective evaluation (clear evaluation system for all culture - culture, capacity assessors, etc.), system design evaluation (determination methods of measurement, etc.), the objective and subjective methods and the performance evaluation 360 degree which gathers reviews those related to employee. It is also the function of human resource development based educational programs, career management, development executives and talent management (Kanellopoulos et al, 1990).

They could give some definitions for the concepts development executives is to control the growth of a company's resources in order to achieve the objectives of the company and is subsidiary to improve the results of the enterprise manager. Also, a definition can be given for the development career is a variety of activities that help the person to fulfill his goals that has. The career planning is also a process where apiece understands what skills and abilities and making plans to achieve its (Aspridis et al, 2013).

At the beginning of efforts to systematic organization started giving role in the personnel department, now the responsibility of the service changed and went through the role of mediator in the role of assessor. Service personnel should be in a relationship assistant / consultant with other areas of the business / organization, and entitles employees 
to learn their rights. Administration staff is either the owner himself (mainly for small and medium-sized enterprises) or a single specific (in this case the director is the person doing the monitoring and coordination of the work) (Cho et al, 2005; Porfiridis, 2008).

Planning of human resource is the most important and basic function of human resources management. The prediction and assessment needs in line with the number of staff required for business goals. However, for a better staffing department personnel it is necessary to understand offer both external and internal environment. The planning of human resource is the most of the important functions (Porfiridis, 2008).

The recruitment of staff is essential to attract candidates to achieve the already defined business goals. Administration is the one that will select those individuals who have the skills for this project of the company. External sources of recruitment are Manpower Employment Organization, various schools, universities from which companies can choose their employees. The selection of staff is performed in various ways, such as with resumes, interviews, information from third parties, contests, announcements, medical exams, recruitment after testing, and finally tests or test (Werther et al, 1985; Papalexandris et al, 2000; Kottler et al, 2009).

Crucial is the training of employees in all organizations seeking after the effective yield. Some effects resulting from education could be to improve the quality and quantity of workers, the best way to execute the project, etc. However the most important role education plays in learning and depends on the stimulation of workers, education practical, theoretical training, and learning new skills. The success of the educational process depends on lectures, meetings, case studies, roles where workers are essentially divided into groups and impersonating a role, where demonstrations are intended to make the job simpler and simulation where the "students" have the proper equipment and solve problems that may arise during the course of their work (Brewster et al, 2007).

Key objectives of development management is to develop the ability to understand the problems of human behavior and the environment and the effects they have on business. Also positive attitude to business and skills development towards adaptation to the conditions constantly change. The final target is to increase the efficiency of workers and executives. To achieve these goals the company's policy should be harmonized, be approved by the leadership, and be consistent with the needs of employees, to enhance learning and provide opportunities to practice and based on the strategic ability and general analysis capabilities (Dessler, 2012).

The performance of employees is considered the completion of a project and includes recording negative assessment of the positive points of project. Linked to the strategic objectives of the company for trying to "unite" somehow workers with the desired results, and helps mainly makes assessment of each employee individually, facilitate planning and development of their employees with the skills notify everyone, encourages managers to study the behavior of existing and finally helps in making decisions about promotions, transfers, layoffs, etc. after a long evaluation period (Hartog et al, 2004).

The basic procedures for a reliable assessment method is to first analyze the work of the position to determine how to achieve the task to develop the way in which we measure the performance and to clarify if the errors are stable or unstable. In fixed bugs no "rigged" similarities where the assessor believes that all features in the same range as one of the other characteristics. In unstable errors are differences between the two evaluators which means that one or both do not appreciate properly (Aspridis, 2013).

Factors influencing behavior is the slope factor, defined as the ability of a person that has to do more than one job. The second factor is the skill level is the difference between skills and inclination "to the fact that they can be taught to the point where the slope requires". The third factor is understanding the work in the way in which it can be spread the understanding of work. The fourth and final factor is the effort, this means that a person is inclined and doesn't perform at the maximum performance (Aspridis et al, 2013).

The remuneration is directly linked to reward and employee satisfaction and consists of direct economic benefit i.e salaries and bonuses and indirect economic benefit i.e holidays, life insurance, etc. Pay systems are effective when employees are paid according to the services they offer and depending on how you paid other employees in similar jobs. Objectively, therefore the objectives of the enterprise are summarized on the issue of workers with the necessary skills. Then the people should not resign if the salaries must be competitive. To ensure fairness means that employees with more qualifications and requirements should be paid more. There should be a rational payment system and a valid wage system, and programs end wages should be managed efficiently. Last but not least the pay systems consist of three categories, direct or fixed remuneration, variable remuneration and other benefits such as holiday pay, marriage, catering, etc (Dessler, 2012)

According to Werther et al (1985:16), more organizations make available a series of opportunities to education. Training and development objectives result from the needs analysis. Trainers can plan the content from the objectives and incorporate many learning principles. According to Werther et al (1985), "human resource development prepares 
individuals for future job responsibilities". The personnel department is involved because it affects people. The target is to manage changes, because that will have as a result to increase benefits and reduce costs. Major changes of human resource include planning, participation, communication and rewards. Nowadays, personnel departments begin to recognize the need for more proactive efforts and this has as a result the provision of education for career, information and counseling. Career planning does not guarantee the success. But is a useful implement for the employees to be ready for the opportunities that arise (Sheard et al, 2004; Clarke, 2006).

According to Brewster et al (2007:7), «personnel remains a highly fragmented occupational grouping; the image of the personnel manager as the general medical practitioner seems far removed from reality». There are changes very important in human resource management. Firstly the involvement of human resource management may be changing, the role of the managers, the impact of outsourcing, and finally shared services and e-human resource management are being felt. The effects of course, are even important. However, it is clear that there may be general trends and directions. Innovation in training is possible for all national settings.

\section{The Development of Human Resource in Public Administration}

The development of human resource in public administration (according to the articles 103 and 104 of the Constitution of Greece) is the continuous education and the training of staff, regardless of the needs of their work and many times be combined with the demands of work and the development of staff. As Papalexandri (1990), citing Morris (1971), mentioned that the development of managers is the systematic improvement of the effectiveness of management while citing Black (1974) is the design and planning for the improvement of management in business. The management development includes not only the education and training but all opportunities that provide the company to further gain experience. To the development contributes the revolution in information technology, the modern forms of administration, the changes in society and the globalization (Dessler, 2012; Papalexandris, 1990; Lawrence et al, 1969).

The programs of home-based training and executive development demonstrate that the development is focused on current and future work, the working group or the whole company, is long and prepares the employee for the future skills (Amy et al, 2012; Dessler, 2012). The most modern method of staff development is e-learning. According to European Commission, e-learning "or electronic learning, also referred to as web-based learning, encompasses a broad range of knowledge transferred through digital technologies, sometimes as a complement to traditional education channels" (http://epp.eurostat.ec.europa.eu/statistics_explained/index.php/Glossary:E-learning.

The optimal utilization of human resource based on the merit, despite the failures, the continuous and objective evaluation, the after-training of employees, on the flexible organizational structures, the optimized use of new technologies and finally the ability to research and develop best practices and abroad (Leigh, 2010). Also necessary changes can be considered regarding the organizational environment, the existence of mechanisms that allow the experimentation with new ideas, opportunities of higher grade for younger members that involved with innovative ideas and potential positive response to the results of successful experiments on organizational and operational changes (Dokos, 2013; Nubler, 1997; Koufidou, ny).

\section{The Local Government in Greece}

The Article 5 of the Treaty for EU guarantees the principle of subsidiarity. This principle ensures that the decisions are taken as close as possible to the citizen and that constant checks are carried out to verify that action at EU level is justified in the light of the possibilities available at national, regional or local level. EU does not take action only if the action is more effective than the corresponding action at national, regional or local level. The Maastricht Treaty established the Committee of the Regions (1994) (http://cor.europa.eu/en/Pages/home.aspx), a political assembly that provides at the local and regional authorities the ability to express their views in the heart of the EU (Smith, 1997).

About the Treaty of Lisbon, the European regions acquire more forces. For the first time, elected local and regional representatives of Europe can, through the Committee, to challenge before the Court of Europe the new legislation of EU, who believe that it violates the principle of subsidiarity, i.e the principle according to which the decisions taken by the authority closer to the citizen (http://www.moi.gov.cy/moi/moi.nsf/All/82216E855729B794C2257AB60055564F?Open Document).

The Greek Constitution 1975/1986/2001/2008 (Article 1) states that "the administration of the State shall be organized in accordance with the decentralized system". Article 3 states that "regional institutions of the state are responsible for deciding the affairs of their region. The central institutions of the state, except in special powers, have the general direction, coordination and control of the legality of regional institutions, as specified by the law". Decentralization 
(Aspridis, 2013) is the process of transfer of powers from the center to the periphery, i.e the transfer of power from the government institutions of the region, while the devolution of powers refers to the transfer of substantial powers of the State institutions of government. The purpose of decentralization is to address local needs where they are presented in order to bring about the development of the regions of the state. The degree of decentralization of a state is purely a matter of political choice. Devolution is the creation of regional public institutions and includes the award decisive powers in them. It is a means of strengthening democracy and helps to increase the efficiency of the state. Through the decentralization of local communities exploit the human and natural reserves that have, in order to further their development and to promote the benefits of their area (Dagtoglou, 1992) (articles 101 and 102 of the Constitution of Greece). The division of the country in thirteen regions based on several criterias, because the current situation, appeared striking disparities between its regions, particularly between the center (central regions) and the periphery (peripheral regions) in terms of their economic situation (Academy of Athens, 2000; I. Spiliotopoulos, ny).

In Article 102, paragraph 1, the Greek Constitution stated that Local Authorities are responsible for the administration of local affairs. As government defined the "self-reactive management i.e management of local affairs by elected representatives" in paragraph 2 states that "local authorities have administrative and financial autonomy". In paragraph 4 stipulates that "the state is at local municipalities supervision recommended solely on legality and may not prevent the initiative and freedom of action" (Hlepas, 2004; Makridimitris, 2006).

The multi-level organization of this system had the effect of overlapping responsibilities between units of different levels, limiting the freedom of action of the units of the lower levels through the numerous directives and guidelines overburden them. Also cause delays in the adoption and implementation of development programs, unnecessary work between departments at various levels which cause unnecessary volume of procedures and bureaucracy and finally overspending resources (Academy of Athens, 2000). In this context, it was considered necessary combination functions neighboring Municipalities in single territories, which will help to improve the functioning and effectiveness of the local governments. In any case, the triptych central state organs - regional state organs - organs of local municipalities need to be treated as a single system that must function properly in accordance with the Constitution and the existing legal framework, but also in daily practice, which will be judged more by the success of the institution of government (Academy of Athens, 2000).

\subsection{The law of Kallikratis}

In Greece the application of the Law "Kallikratis"1 (L. 3852/2010) are shown again two degrees of local government. The first is the 325 Municipalities and operated. The function of the local municipalities is regulated by the provisions of $L$. 3463/2006 (Code of Local Municipalities and Communities), the decrees and circulars issued after the enactment of the Law and the 3852/2010. The plan is Kallikratis continuity the plan Kapodistrias (law 2539/1997) of the Greek State. The benefits for the state and the citizen is initially to reduce operating costs, to restart the country's development and that there is confidence in the institution and the world of government. Also to better serve citizens, to provide high quality services and to encourage citizen participation.

According to J. Ragousis (2010), former Minister of Interior, who recommended the program goal is to be no municipalities have a population of less than 25,000 for Athens and Thessaloniki and 10,000 for the rest of the country. The project for Kapodistrian municipalities failed and gave the order to Kallikratis plan which will seek to achieve institutional changes did the Kapodistrias plan.

After the program there Kallikratis the institution of decentralized administration that essentially replaces the 13 regions of Kapodistrias. The 13 regions under Kallikratis is the region of Eastern Macedonia and Thrace based in Komotini, the central region of Macedonia in Thessaloniki, the region of western Macedonia based in Kozani, the region of Thessaly, Larissa, the region of Epirus in Ioannina, the region of Ionian Islands Corfu based, the region of western Greece in Patras, on the Peloponnese region in Tripoli, the region of Attica Athens-based, the region of Crete in Heraklion, the region of the South Aegean based Ermoupoli and finally the northern Aegean region based Mytilene.

According to L. 3852/2010, the responsibilities for the new Municipalities are concerning the powers of the current prefectures. Apart from the responsibilities transferred and services a long with their staff and among others provided online collaboration with other public entities, online transactions that are interconnected with the banking system and access to social services. There are municipalities that innovate and provide such information electronically to their residents. The program provides Kallikratis reduction consultants from 5 to 3 in apartments numbered less than 1,000

${ }^{1}$ The program took his name by the famous architect of antiquity Kallikratis and with Iktinos were the two leading architects of the second half of the 5 th century in ancient Greece. In their works we find the perfection. 
residents and from 3 to 1 in apartments with residents' number less than 500 . This reduction, but does not work for the benefit of municipalities since neither reduces costs but also leads to flexible bodies under the program. Local councils will be elected by a single ballot, because it is trying to avoid partisan and party match.

The program of Kallikratis up the decentralized state in 7 sections called the devolved administrations, which included some state responsibilities such as spatial planning. The formation of a small number of administrative units should if it means pushing for stronger decentralization to local and regional communities. Also attempted reforming the governance system and corresponding foundation system. This creates a new "government institution" by the Executive Committee aims to ongoing assessment, monitoring, and accountability of the executive bodies of municipalities and regions. However not include more extensive set of systematic functioning of elected councils.

Preferable would be the law itself to organize and upgrade best elected councilors and especially their audit functions. Important however strengthen the system offers "internal decentralization" of local municipalities. The abolition of the current system has as center the Mayor about the program of Kallikratis through the establishment of six new structures. In the context of government committee will work to municipalities Executive Committee will be composed of the mayor and deputy mayors who will be responsible for all areas of policy. Advisory body to municipalities over 10,000 inhabitants will be the new Municipal Consultation Committee composed of 25-50 members - representatives of local community stakeholders and residents.

The new architecture of governance and decentralized administration (L. 3852/2010), proceeded to change the administrative division of Greece and redefined its self-governing units, the mode of election of the institutions and their responsibilities. Created 13 regional governments, with elected Prefect Board and 7 decentralized administrations

By the L. 3852/2010 "New Architecture of Local Authorities and Decentralized Administration - Program of Kallikratis" structural changes in the local organizations are adopted. This Law combine the Local Authorities (Municipalities and communities) from 1034 to 325 municipalities, replacement the 56 prefectures to 13 elected regions which are divided into regional units, the 13 state regions are formed in 7 decentralized administrations and last but not least the tenure of the Mayor and the Prefect converted from four to five years with elections simultaneously with the European elections.

The operational program recommends a comprehensive set of complementary interventions, which are expected to address the underlying problems of the public administration, regarding the key factors administrative capacity (human resources, legal framework, structures and systems) and both in terms of shaping public policies and at the level of implementation of the services of the Public Administration (in website http://www.tovima.gr/society/article/?aid=378846).

The new architecture of governance and decentralized administration (L. 3852/2010), proceeded to change the administrative division of Greece and redefined its self-governing units, the mode of election of the institutions and their responsibilities. Created 13 regional governments, with elected Board and 7 decentralized administrations (in website http://www.tovima.gr/society/article/?aid=378846), the general secretaries of which took over the responsibilities of the old regions and 74 regional units (Ragousis, 2010; Text Public Consultation, 2010).

The program of Kallikratis is early to judge. It is an ambitious program with positive elements, but applies to a period where there are adequate resources (human and financial) and there is a general frustration in the country. The program aims to further strengthen the municipalities, to save resources and to absorb EU funds. Despite these early findings on the effectiveness and the extent achieved the targets set have begun to be exported. According to a survey of workers in Kallikratis municipality of Thessaly, it understands that the evaluation program must be carried out at three levels. Its effectiveness towards the citizens and the local community in relation to the financial and end in relation to the better organization of the new municipalities. According to this new research program planners penalizes the old municipalities that are no longer capitals Kallikratis Municipalities, not helped in substantial savings, did not change the structural organization of municipalities and citizens do not end better served or not changed anything in convenience due to the existence of Citizen Service Centers (Chrysanthakis, 2010; Akrivopoulou ,2012; Triantafilopoulou, nd; http://notia-press.gr/index.php/south-cities-news/glyfada/2572-provlimatikos-o-kallikratis-notia-press).

\section{The Municipality of Trikala}

The municipality of Trikala is a municipality of the region. It resulted from the merger of eight existing municipalities. The extent of the new municipality is $608.48 \mathrm{~km}^{2}$, and a population of 74,592 inhabitants. The Municipality of Trikala divided into 8 "Municipal Modules", which correspond to the eight municipalities merged. Each city section is divided into "communities", which correspond to the repealed Pensions local municipalities. Current local communities of the municipality, was autonomous communities and municipalities before the implementation of the program Kapodistrias (in website http://www.trikalacity.gr)). 
Figure 1: Employees by category

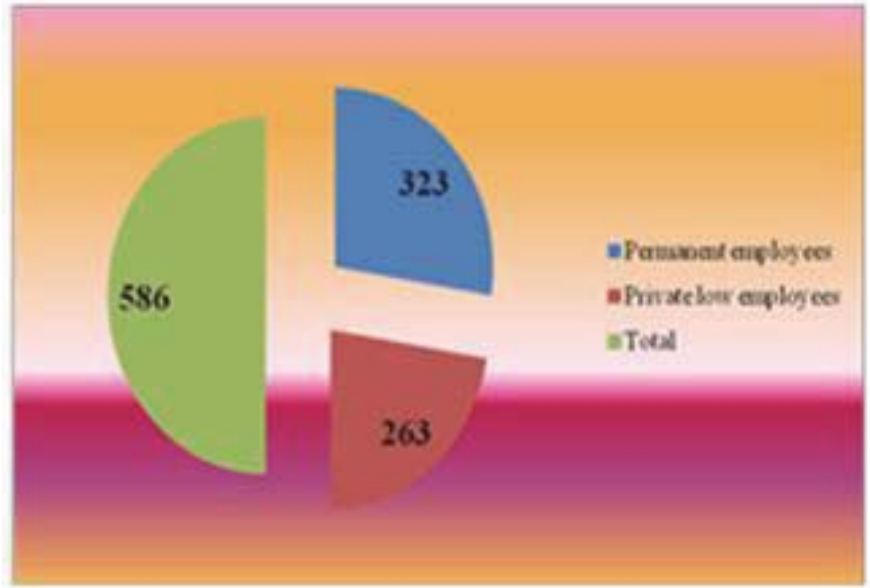

Source: Department of Personnel Management of Municipality of Trikala

Figure 2: Employees by Educational Level

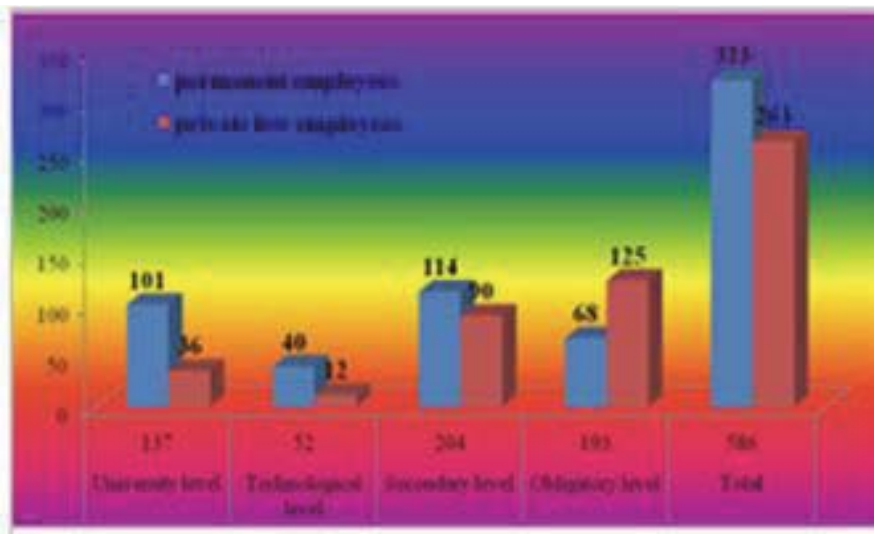

Source: Department of Personnel Management of Municipality of Trikala

Figure 3: Employees by age

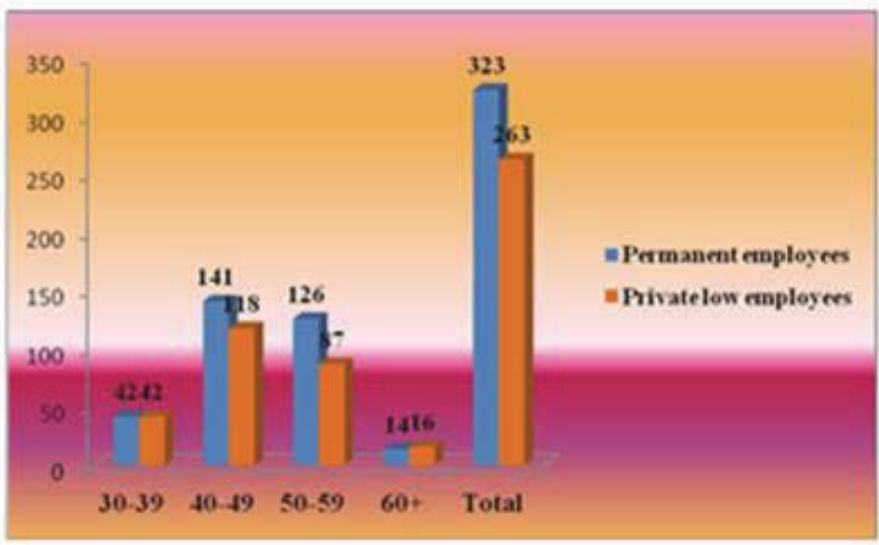

Source: Department of Personnel Management of Municipality of Trikala 
Figure 4: Employees by sex

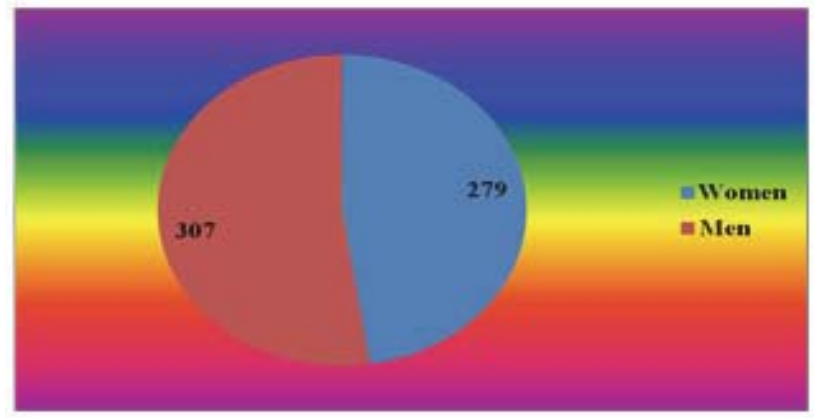

Source: Department of Personnel Management of Municipality of Trikala

\section{The Research}

The case study is an in-depth examination of a particular facet of a social phenomenon, such as a workplace. The main purpose of the case study can be both descriptive and in-depth study of a particular case (Flyvbjerg, 2006; Saunders, 2009). The method that used is the method of semi-structured interview in which the interviewer usually starts from an original subject, but can adapt the interview to the interviewee's answers because although we have at our disposal a wide range of predefined questions, but there is the flexibility to modify the questions according to the needs of interview. So we have at our disposal a flexible and powerful tool that allows the formation of an overall and comprehensive picture of the participants' perceptions (Babbie, 2011). The interviewers required to follow all the instructions necessary for the conduct of a successful interview. Such instructions referred at the evaluation of behaviors, familiarity with the questionnaire faithful reproduction of the questions and end the accurate recording of responses.

A number of 55 employees from the Municipality of Trikala, of the Region of Trikala, were interviewed in a working a total of 586 employees of the City of Trikala (324 permanent and 262 private low employees). A period of 20 days was available to prepare the negotiations, methodological, material file Municipality and others. The sample has been provided by the department of Personnel of the municipality. A pilot test preceded the final distribu1tion of the interviews, so as to reassure the research's instrument applicability. The quantitative analysis of the interviews' information was done with the use of statistical software, like SPSS and Excel. There was a telephone contact with the Mayors and their representatives, whereby there was a brief discussion on research and anticipated results. As soon as the questionnaire's preparation was done, a telephone contact, with the sample, for informing them about the distribution of questionnaires to them, preceded e-mail sending.

\subsection{The structure of the questionnaire}

The questionnaire included a series of questions. The first section of the interview recorded the level of education and the skills of the workers, the work involved and any wishes change. The second investigated the job satisfaction of employees and the specific strengths and weaknesses. The third recorded changes positions and job items. The fourth investigated the cooperation with the civilian personnel and other workers and any problems encountered. In the fifth group it was attempted to elicit about the conflicts of workers. The sixth has investigated user satisfaction from the current job. The seventh has calculated the satisfaction from their remuneration. Finally the eighth section refers to utilization and the development of human resource within the program Kallikratis and opinions of the subjects of the research in it.

\subsection{The results of the research}

In Trikala, it is obvious that, there is a strong discontent of employees from cronyism, lack of satisfying fees, from the devastation of the institutions of local government and finally the lack of exploitation of workers. To the survey involved totally 55 people, of which 46 are permanents and 9 low private employees. 


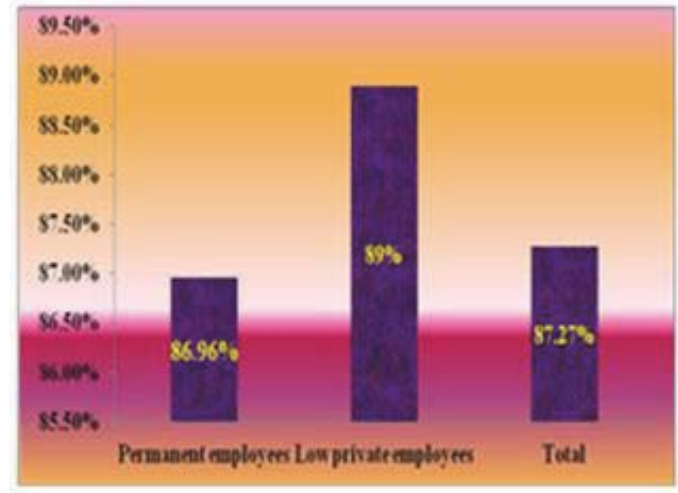

Figure 5: Desire for training

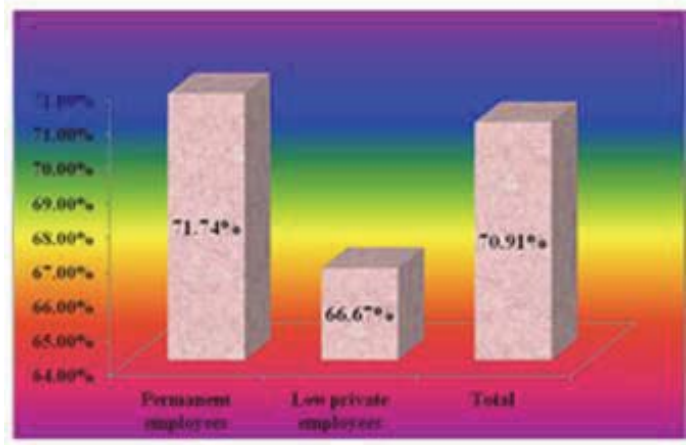

Figure 7: Utilization of permanent servants

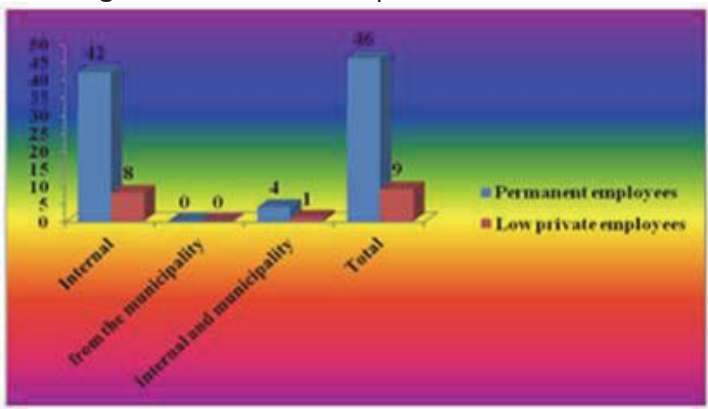

Figure 9: Motivational factors

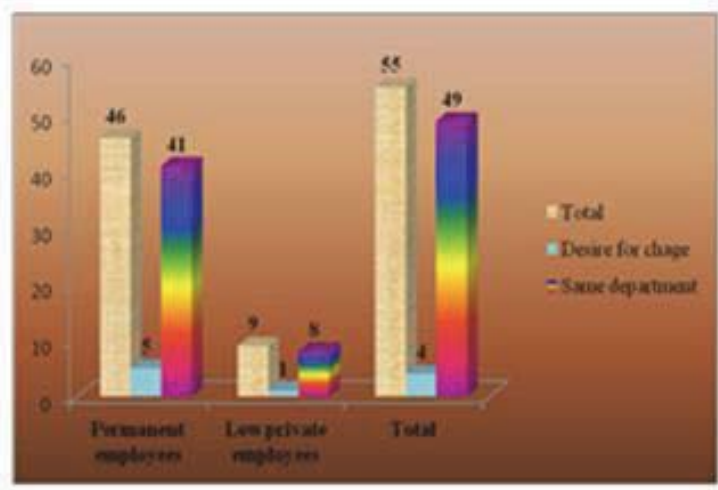

Figure 6: Desire for change

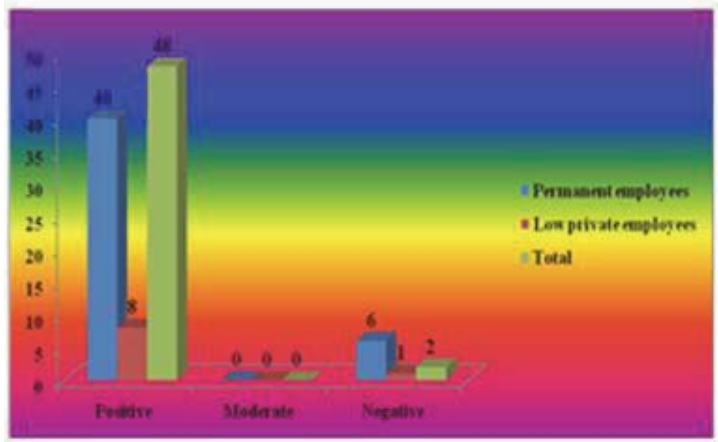

Figure 8: Satisfaction of employees

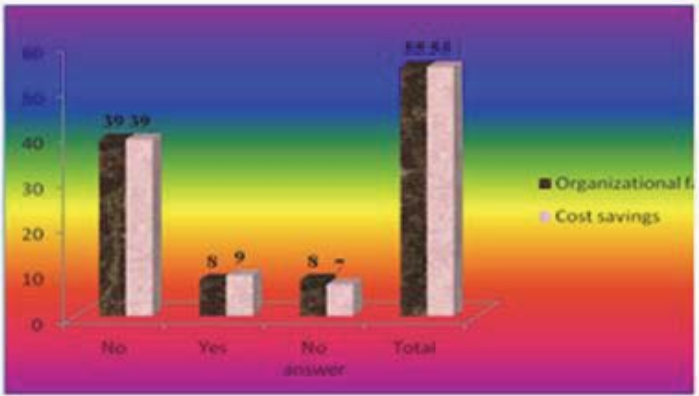

Figure 10: The exploitation of workers and improvement of the organizational structure

Each interview last approximately 10 minutes and almost all the officials of Secondary and Higher Education level were met. From the diagrams above we conclude that the vast majority (89\%) staff members want to educate themselves on various subjects. From figure 6 we conclude that the employees of the municipality to percentage $89 \%$ do not want any change in employment status. While the next chart we see that almost $71 \%$ of them consider that tapped into the structures of the municipality. From the figure 8 we conclude that the majority of employees of the municipality is satisfied with their work and the job in which they hold. Finally, figure 9 shows that the main factors of motivation is internal and continually those from the workplace. We therefore observe that there is disagreement between workers in the two municipalities and this may be due to the size of the municipalities. Employees judge negatively the program Kallikratis on dimension on organizational development and exploitation but also financial savings that could not be made.

In the municipality of Trikala, the results were even more discouraging. With the exception of some employees, ie S10 and S12, all the remaining respondents answered negatively for the overall usefulness of the program Kallikratis. Particularly, all the workers replied that Kallikratis did not help either organizational nor the utilization and development of the employees. The Law of Kallikratis created more bureaucracy, committees, and the concentration of responsibilities and structures. From them that responded positively the employee is not resident in the municipality and not working in the field of her study (is nursery and she is working on KAPI [Open Care Center for the elderly] of the municipality) and does not want any change in her work. Generally, the municipalities do not capitalized on existing organizational 
structures, and were not ready in practice level to meet the needs of the new municipality and finally did not help to the full development of human potential.

Also, there was not trained staff for the confrontation with new situations. Finally, did not help the development of the human resource because there were not special seminars on the object of their work or the importance of the new program. It is characteristic the answer of one of the respondents who mentioned that "a perverse mind created the program Kallikratis". The employees have not received the adequate training to meet the growing needs of society.

It is a moral duty of all to carry out the institutional reforms that is necessary in the local area to achieve the best possible result. It is the responsibility of politicians to respect the institutions to be more effective administration, to apply laws that have been both national and European level, and then the citizens themselves to become shareholders and society as a change of administration.

\section{Conclusions}

Human capital is the most valuable of every organization and the representative in every society. In the period of economic crisis, the organizations require to strengthen the role of Human Resource Management. Also, must provides the necessary motivation, to strengthen the team spirit, to create a protective grid opposite to the economic downturn, to create team spirit of innovation and finally request the active involvement of employees in making decisions for improving the practices and methods of business (Sdrolias et al, 2013).

Companies require to face their employees as capital and provide the necessary instruments, with which they will be selected, exploited, developed and finally exploit the workers. In order to become a reality the science of administration require to use the technologies of computer science and especially the themes of recruitment and measurability of the performance of employees (Sdrolias et al, 2013).

The interviews of employees from the Trikala municipality demonstrated that employees are motivated. The motivation is primarily internal and due to the same desire of workers to contribute to society, then the motivation comes from the need to secure to the livelihood of their employees. Generally, the interviews showed that the first hypothesis is verified. Of all the interviews distinguish the urgent need for further education and training of employees and especially in matters relating to the new institutional framework.

Employees are completely satisfied with the fees that they had before the financial crisis (in reference both to their work and their performance). They are disappointed with their fees for the past four years, which can not provide them with to the living. They are generally satisfied with their work, but not at such a high level. It is rational because after applying the last law and the economic crisis have excessive workload without a corresponding recognition.

There is a satisfactory degree of identification about the municipality and employees that working without this meaning that is at a high level the degree of devotion. Generally, don't appear conflictions with civilian personnel or with their colleagues. Whatever conflicts there are official character and dealt directly with the contact. Employees of the Municipality believe that program Kallikratis does not improve the offering services, did not reduce the economic costs and finally the most important is not utilized human resources and skills of employees.

This study hopes to contribute to the formulation of a proposal for the enhancement of human resources in Municipalities of Kallikratis, placing the right person in the right place and finally to formulate the criteria for achieving this goal. In this way, the municipalities will become more efficient and productive and will better serve their citizens. According to the results of the research, the most employees active because of the internal motivation, and desire the continuous training and education (to the issues that related the new technologies and the best management practices). Also, demonstrated that that contest their assessment, especially that it takes place under the threat of dismissal. Finally, the same services require to contribute at the development of their employees and organizational change.

There were enough problems during the preparation of this study. The most basic was that it made the same time making plans for the evaluation of human resource and the start of the availability of the employees. That had as a result many workers to refuse to answer or not to answer honestly and be wary. Also the same period were planned the municipal elections so they do not have the necessary time available to them. It had not finished the process of the data of human resources in the Municipality of Trikala so we do not have the actual data but only those elements of the Agency's Internal Service. Also, the sample consists of small and medium-sized municipalities so that results can be generalized only to them.

\section{Epilogue}

According to Elton Mayo (1920) (Professor of Industrial Management, Harvard Business School) "so long as commerce 
specializes in business methods which take no account of human nature and social motives, so long may we expect strikes and sabotage to be the ordinary accompaniment of industry". The modernization of the Municipalities of the new generation can not but relies on manpower. Regarding the utilization of new technologies focused actions in adapting of the skills for young workers by incorporating knowledge on new technologies, filling the gaps in specialized strains and the training of employees in the organization, administration and information technology (Maistros, 2009).

\section{Bibliography}

Academy of Athens (2000). Decentralization and government. Findings and recommendations, Athens (in Greek).

Akrivopoulou, Chr., Dimitropoulos, G., Koutnatzis, S.-I., (2012). "The "Kallikratis Program" : The Influence of International and European Policies on the Reforms of Greek Local Government", Instituzioni del Federalismo, 3/2012 (653 - 693).

Amy Yeo Chu May, Cartr St., (2012). "From "learning" to "employabiblity" : Informing successful teamwork through social and emotional competencies", Economics, Management and Financial Markets, Vol. 7(3) (11 - 30).

Anderson, G., (1993). Managing Performance Appraisal Systems, Oxford : Blackwell Publishers.

Andronopoulos, B., and Mathioudakis, M., (1988). Greek administrative history, regional government, local government, Athens : Administrative Reform (in Greek).

Aspridis, G., (2013). Introduction to the political and administrative organization of the Greek state, Athens : Propobos (in Greek).

Aspridis, G., Blanas, N., Tsartsara, An., Karaxalios, G., Kiriakou, D., Meleas, J., (2013). "Assessment of e-Learning Methods in Public Administration. The Case of the Greek National School of Public Administration and Local Government", International Journal of Human Resource Management and Research, Vol 3, Issue 5 (19-36) (in Greek).

Brewster, C., Sparrow, P., and Vernon G., (2007). International Human Resource Management, $2^{\text {nd }}$ edition, London : CIPD.

Cohen, L., and Manion, L., (1994). Methodology research in education. Athens : Metaixmio (in Greek).

Cho, S., Woods, R., and Mayer, I., (2005). "Examining the impact of Human Resource Management on organizational performance", Academy of Management, A1.

Chrysanthakis, Ch., (2010). Kallikratis, Athens : Nomiki Bibliothiki (in Greek).

Clarke, N., (2010). "The impact of training programme designed to target the emotional intelligence abilities of Project Management", Academy of Management, 28 (461-468).

Collective (1994), Systems Management metropolitan areas, Conference of the Department P.E.D.D., University of Athens, Athens Komotini : Ant. N. Sakoulas (in Greek).

Dagtoglou, P. (2002), The New European Treaties, Athens - Komotini : Ant. N. Sakoulas, (in Greek).

Dessler, G. (2012). Human resource management - Basic concepts and modern trends, Athens : Kritiki (in Greek).

Dokos, Th., (2013). "Utilization of human resource", Kathimerini, 3-7-2013 (in Greek).

Flyvbjerg, B., (2006). "Five misunderstandings about case-study research", Qualitative inquiry 12.2 (219-45).

Handler, H., Koebel, B., Reiss, Ph., and Schratzeustaller, M., (2004), «The size and performance of public sector activities in Europe», Study prepared for the European Commissions Competitiveness Report.

Hartog, D., Boselie, P., and Paauwe, J., (2004). "Performance Management: A model and research agenda". Applied Psychology : An international review, 53 (4), (556-569).

Hegewisch, A., and Brewster, C., (eds.), (1993). European developments in human resource management, Bedfordshire : Granfield University-School of Management.

Hitiris, L. (2001). Organizational behavior, Athens : Interbooks (in Greek).

Hlepas, N. - K., (2004), Perspectives of local democracy. A Greek-German dialogue on local government, Athens - Komotini : Ant. N. Sakoulas (in Greek).

Kanellopoulos, Ch., and Papalexandri, N., (1990). Utilization management development personnel and improve organization, Athens : International Publishing (in Greek).

Kloot, L. and Martin, J., (2000). "Strategic performance management: A balanced approach to performance management issues in local government", Management Accounting Research, Volume 11, Issue 2, 2000 (231-251).

Kottler, Ph., and Lee, N., (2009). Corporate Social Responsibility, Athens : Kritiki (in Greek).

Koufidou, St., (ny). Basic research for the integration of strategic use of human resources and knowledge management, questionnaire on the project "Managing organizational knowledge for Greek enterprises" under Action 4.5.1. Operational Programme Competitiveness (in Greek).

Kvale, S., and Brinkmann, S., (2008). Interviews : Learning the craft of qualitative research interviewing. CA : Sage Publications, Incorporated.

Latham, G., (2004). "The motivational benefits of goal - setting", Academy of Management Executive, Vol 18, No 4.

Leigh, An., (2010). Management, Athens : Kritiki (in Greek).

Lawrence, P., and Lorch, L., (1969). Developing organizations : Diagnosis and action, Massachusetts : Addison - Wesley.

Maistros, P., (2009). The three waves of public administration reform in Greece [1975 - 2015+], Athens : Papazisis (in greek).

Makridimitris, A. (2008). Public Administration - Administrative Organization, Athens - Thessaloniki : Sakkoulas (in Greek).

Makridimitris, (2006). Public administration - Information logistics, Sakkoulas : Thessaloniki (in Greek).

Mishra, S., (2010). "Implementing SHRM" VSRD - TNTS, Vol 1(2) (103-109). 
Mouza-Lazaridi, A.-M., (2006). Human Resource Management, Athens : Kritiki (in Greek).

Noe, R., Hollenbeck, J., Gerhart, B., and Wright P., (2009). Human Resources Management: Gaining a competitive advantage, Athens : Papazisis (in Greek).

Nubler, I., (1997). Human resources development and utilization in demobilization and reintegration programs, Paper 07, Bonn : B.I.C.C.

Papalexandris, N., (1990). "Development of personnel. Contents, development, operational framework" to Kanellopoulos, Ch., and Papalexandris, N., Development of personnel, Athens : Interbooks (in Greek).

Papalexandris, N., and Nikadrou, I., (2000), "Benchmarking employee skills : Results from best practice firms in Greece", Journal of European Industrial Training, Vol. 24 Iss: 7, pp.391 - 402.

Porfyridis, G., (2008). "Human Resource Management", Administrative Update, Vol. 47 (36-49) (in Greek).

Ragousis, J., (2010). Speech by the Ministry of Interior, Decentralization \& e-Government, the Cabinet during the presentation of "Kallikratis", Athens (in Greek).

Robbins, St., Decenzo, D. and Coulter, M., (2012). Business Administration - Principles and Applications, Athens : Kritiki (in Greek).

Saunders, M., Lewis, P. and Thornhill, A., (2009). Research methods for business students. 5th ed. Harlow: FT Prentice Hall.

Schermerhorn, R. J., (2010). Introduction to management, NY : John Wiley and Sons, Inc.

Schuler, R., and Jackson, S., (2010). Global talent management initiatives for global talent challenges, proceedings of the 11th International Human Resource Management Conference, Birmingham, England : Aston University, June 9-12.

Schuler, S. and Jackson, S. (2006). Human resources management: International perspectives, $9^{\text {th }}$ edition, Mason : Thompson South Western.

Sdrolias, L., and Aspridis, G., (2013). Announcement on theme: "The challenge of the human resource management in the period of economic crisis", 5th Conference on Administrative Sciences: Reorganization of Administration and the State in after the 'Memorandum' era, Komotini 28 - 30/11/2013.

Sheard, A., and Kakabadse, A., (2004). "A process perspective on leadership and team development", Journal of Management Development, Vol 23, No 1 (7-106).

Smith, Gr. J., (1997). Strategic business, Athens : Compupress (in Greek).

Spiliotopoulos, I., (ny), Decentralization - Attempt bounding along the material competence of state regional institutions. The region as a decentralized unit of the State (L. 2503/1997), Ph.D. Thesis submitted of the Law School, University of Athens, under the supervision of Professor S. Ransom, Athens (in Greek).

Stephen R., Decenzo D., and Coulter M., (2012). Management - Principles and applications, Athens : Kritiki (in Greek).

Taylor, Fr., (2007). Principles of Scientific Management, Athens : Papazisis, (in Greek).

Triantafilopoulou, Ath., (ny). Kallikratis. Employment in local government, Athens : Hellenic Agency for Local Development and Local Government (in Greek).

Vasudha rani Vaddadi, (2014). "Survey on methodology and example of mapper / reducer / combiner for big data", European Journal of Academic Essays 1(5): 1-4, 2014.

Vaxevanidou, M., and Reklitis, P. (2008). Management of Human Resources, Athens : Propobos (in Greek).

Werther, W., and Davis, K., (1985). Human resources and personnel management, $3^{\text {rd }}$ edition, NY : McGraw-Hill.

\section{Institutional framework}

Mission number 173/2013 «Decision of the Executive Committee Amended Internal Services Agency Municipality of Trikala», Official Newspaper of the Greek Government, 13/1/2014 (in Greek).

L. 3852/2010 «The new architecture of governance and decentralized administration - Program Kallikratis» (Official Newspaper of Greek Government 87A-7/6/2010).

Ministerial Decision 45892/2010 «Primary and secondary OTA the Country by L. 3852/2010 and apportioning population in local communities of Article 2, § 4, of L. 3852/2010, which cannot be allocated due to missing data location», (Official Newspaper of Greek Government 1292/11-8-2010).

Greek Constitution (2008), as revised by the Greek Parliament of 27/5/2008.

L. 3584/2007 «Validation of the Code of Municipal and Community Employees», (Official Newspaper of Greek Government 143A).

L. 3463/2006 «Ratification of the Code of Municipalities and Communities» (Official Newspaper of Greek Government 114A'/8-6-2006).

L. 2539/1997 «Establishment of primary local government», (Official Newspaper of Greek Government 244 A'/4-12-1997).

\section{Websites resources}

http://www.trikalacity.gr/, accessed on 7/12/2013.

http://epp.eurostat.ec.europa.eu/statistics_explained/index.php/Glossary:E-learning, accessed on 30/4/2014.

http://notia-press.gr/index.php/south-cities-news/glyfada/2572-provlimatikos-0-kallikratis-notia-press, accessed on 30/4/2014.

http://www.moi.gov.cy/moi/moi.nsf/All/82216E855729B794C2257AB60055564F?OpenDocument, accessed on 30/4/2014.

http://cor.europa.eu/en/Pages/home.aspx, accessed on 30/4/2014.

http://www.pthes.gov.gr/, accessed on 11/5/2014.

http://www.library.hbs.edu/hc/hawthorne/04.html, accessed on 11/5/2014. 